\title{
EXPORT PROMOTION CHANGES OF SME'S FOR EXPORT EXPANSION DIRECTIONS DEVELOPMENT IN LITHUANIA
}

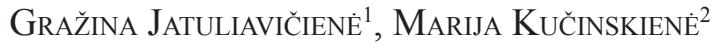 \\ Vilnius University (Lithuania)
}

\begin{abstract}
The article aims to show that conditioned by globalization processes integration tendencies in the world economy stimulate the search of new export expansion directions and development methods. Their evaluation and implementation are important driving forces for national economic growth and sustainable development of regions. Current Lithuanian state's position in export promotion, as it enters into exchanges with the ever-changing global environment, must be conceptually justified, enabling equal participation in the international trade and the ability to withstand globalization's challenges. Most importantly, export promotion and development mechanisms and instruments should allow for timely responses towards the increasing liberalization of economic relationships and encourage the introduction of prerequisites for the acceleration of economic growth through export expansion.

KEY WORDS: internationalization, globalization, SME's, export promotion, export development.-
\end{abstract}

JEL CODES: F130; F140; F150; O110; R110.

\section{Introduction}

The new era of globalization, being operated through World Trade Organization (WTO), and marked by liberalization of trade through elimination of all physical and fiscal barriers, has unfolded multitude of opportunities and challenges. Constantly changing global business environment encourages the search for new growth opportunities, thus creating background for the stimulation of international business relationships. International trade is a key feature of economic globalization. Economic theory as well as empirical evidence clearly shows that countries which are more open to trade are also those that grow the fastest.

Regarded as priority export orientation of the national economy is expected to ensure its sustainable and dynamic progress, economic and financial security and, in the end, growth of common wealth. Increased liberalization of international trade that resulted from globalization processes has brought pressure to bear on Lithuanian exporters to be more competitive both in price and quality to succeed in the European Union and global market. Lithuania had adopted export orientation as a development policy. Yet, Lithuania's export performance has remained not enough.

Export promotion measures that can be utilized under the current World Trade Organization (WTO) system can be treated as the tool for economic development. State support for exporters becomes a necessity due to inevitable competition with economy subjects from other states who are in a more favorable position. This

Gražina Jatuliavičienè - Vilnius University (Lithuania), Faculty of Economics, Business Department, Lecturer, Doctor of social sciences, scientific interest: export development.

E-mail: grazina.jatuliaviciene@ef.vu.lt

Tel.: +370 52193230

2 Marija Kučinskienè - Vilnius University (Lithuania), Faculty of Economics, Business Department, Head of Business Department, Professor, Doctor of social sciences, scientific interest: business strategies.

E-mail: marija.kucinskiene@ef.vu.1t

Tel.: +370 52366137 
advantageous position is acquired not only through the longer experience in the global market but also from effectively functioning export promotion processes management system in their countries.

States are not always capable of fully implementing export development due to specific restrictions that exist internally. Management of successful export development processes is a complex task, as it requires a lot of efforts, resources and persistence in comparison with traditional export promotion methods. Consequently, it defines concentration of theorists' efforts for new export development strategic directions formation, new internationalization and export development trajectories models creation. The challenges in the management of export development in the context of global area create new requirements for the states, their national institutions and economy subjects. They are challenged to adopt new strategic export development decisions that would encourage focus on the creation and acceptance of new skills. Such innovations would allow overstep the boundaries of traditional business and enable the acquisition of competitive advantage in the global area product markets.

Three major issues have recently emerged that influence export promotion: growing interest in the environment and sustainable development, the importance of small and medium-sized enterprises (SMEs) as exporters and the scope for increasing trade in goods and services. The export potential of small and medium-sized enterprises has been a growing subject of interest. The current trend points strongly towards a sustained growth in this share, supported by expanding output and employment. Recognizing their growth potential, most governments in developing countries are giving priority to SMEs through policy support and other incentives.

The main aim of the article is to reveal the importance of small and medium- sized business for export growth and to review export promotion and development impact taking into account the factual export performance of Lithuanian SME's s and their attitude to export promotion activities.

Research methods: logical analysis and synthesis of related literature, comparison and generalization, deduction and conceptualization, empirical research.

\section{Internationalization trajectories}

Current dynamic globalization processes create international business environment that radically differs from the former providing new challenges and trade-offs. Literature studies reveal that separate authors present different definitions of globalization but uniting features in all definitions are that they highlight the trend towards greater political, economical, cultural and technological interdependence among national institutions and economies (Czinkota, Ronkainen, Moeffett, 2005; Daniels, Radebaugh, Sullivan, 2007; Hill, 2009). Discussing the current peculiarities of the global economy it is useful to evaluate as it opens possibilities to enter into new markets, provides extensive choice of the human and other resources and creates competitive pressure (Kucinskiene, Jatuliaviciene, 2002). Market openness, associated with globalization, has increased the speed, frequency and magnitude of access to worldwide markets, including all tangible and intangible aspects of commerce thus attracting attention of all concerned: both theorists of international business, state institutions, interested in export development and business sector enterprises.

The stimulation of rapid globalization has tremendously influenced the patterns of firms' internationalization. The term internationalization has been defined differently by many scholars depending on their field of research. Johanson, Vahlne (1977), early developers of the idea of internationalization, have defined it as a gradual and incremental process in which the firm involves on the international markets through a series of incremental stages. The broadest definition that can be applied in every single concept developed is that internationalization is the process of increasing involvement in international markets (Welch, Luostarinen, 1988).

There are many empirical researches existing that analyze the process of internationalization of small and medium-sized enterprises (SME's). The patterns of internationalization, developed by some of the authors, involved into internationalization patterns research, and described as a sequence of stages based on a mixture of classification criteria, including length of export criteria, export involvement, volume of exports as a percentage of sales, countries exported to, etc. are presented in Table 1. 
Table 1. Different perspectives to internationalization stages

\begin{tabular}{|c|c|c|}
\hline Author/Year & Criterion & Specification of stages \\
\hline $\begin{array}{l}\text { Johanson, J., } \\
\text { Wiedersheim, P. F } \\
(1975)\end{array}$ & $\begin{array}{l}\text { Market entry } \\
\text { mode }\end{array}$ & $\begin{array}{l}\text { Stage 1. No regular export activities } \\
\text { Stage 2. Export via independent representatives (agent) } \\
\text { Stage } 3 \text {. Sales subsidiary } \\
\text { Stage } 4 \text {. Production/manufacturing }\end{array}$ \\
\hline $\begin{array}{l}\text { Bilkey, W. J., } \\
\text { Tesar, G. (1977) }\end{array}$ & $\begin{array}{l}\text { Sequence of } \\
\text { learning stages }\end{array}$ & $\begin{array}{l}\text { Stage 1. Management is not interested in exporting and would not even fill } \\
\text { an unsolicited order } \\
\text { Stage 2. Management is willing to fill unsolicited orders, but makes no } \\
\text { effort to explore the feasibility of active exporting } \\
\text { Stage 3. Management actively explores the feasibility of exporting } \\
\text { Stage } 4 \text {. The firm exports experimentally to some psychologically close } \\
\text { country } \\
\text { Stage 5. The firm is an experienced exporter to that country } \\
\text { Stage } 6 . \text { Management explores the feasibility of exporting to additional } \\
\text { countries, psychologically more distant }\end{array}$ \\
\hline $\begin{array}{l}\text { Cavusgil, S. T. } \\
(1980)\end{array}$ & $\begin{array}{l}\text { Export } \\
\text { involvement }\end{array}$ & $\begin{array}{l}\text { Stage1. Experimental involvement } \\
\text { Stage2. Active involvement } \\
\text { Stage3. Committed involvement }\end{array}$ \\
\hline $\begin{array}{l}\text { Johanson, J., } \\
\text { Wahlne, J. E. (1990) }\end{array}$ & $\begin{array}{l}\text { Resource } \\
\text { commitment }\end{array}$ & $\begin{array}{l}\text { Stage1. Irregular export activities } \\
\text { Stage 2. Export via independent sales representative } \\
\text { Stage 3. Establishment of overseas sales subsidiary } \\
\text { Stage 4. Establishment of foreign manufacturing subsidiaries }\end{array}$ \\
\hline $\begin{array}{l}\text { Kotabe, M., } \\
\text { Czinkota, M. R. } \\
(1992)\end{array}$ & Experience & $\begin{array}{l}\text { Stage 1: Partial Interest in Exporting. Prepared to fill an unsolicited export } \\
\text { order, but does not make the effort to explore the feasibility of exporting } \\
\text { Stage 2: Exploring Exports. Actively exploring the feasibility of exporting, } \\
\text { but exporting less than } 5 \% \text { of total sales } \\
\text { Stage 3: Experimental Exporter. Exporting on an experimental basis to } \\
\text { countries that are geographically close or which share a culture similar to } \\
\text { the domestic market, with exports representing over } 5 \% \text { of total sales } \\
\text { Stage } 4 \text { : Emerging Exporter. Export sales exceeding } 5 \% \text { of total sales; ready } \\
\text { to adjust export offerings to changes in the commercial environment, but still } \\
\text { exporting only to countries that are close geographically or culturally } \\
\text { Stage 5: Experienced Exporter. Export sales are greater than } 5 \% \text { of total } \\
\text { sales; currently exploring the feasibility of exporting to additional countries } \\
\text { that are distant and have different cultures }\end{array}$ \\
\hline $\begin{array}{l}\text { Albaum, G., } \\
\text { Duerr, E., } \\
\text { Strandskov, J. } \\
(2005)\end{array}$ & $\begin{array}{l}\text { Choice of } \\
\text { countries for } \\
\text { exporting }\end{array}$ & $\begin{array}{l}\text { Stage 1. No interest in exporting } \\
\text { Stage 2. Fill unsolicited orders } \\
\text { Stage 3. Explore feasibility of exporting } \\
\text { Stage 4. Export on experimental basis to psychologically close country } \\
\text { Stage 5. Experienced exporter to country of stage } \\
\text { Stage 6. Explore feasibility of exporting to other countries }\end{array}$ \\
\hline
\end{tabular}

Passing the stages reflect evolution of orientation from primarily a domestic firm to a global player. Internationalization entails a notion of exchange, or, more precisely, trade, and progress through stages leads a firm presumably ending with no longer being solely an exporter but introducing some forms of overseas production. Therefore, as Dicken (2003), Hill (2009) point out, economic activities are becoming not only more internationalized, but that, more significantly, they are becoming increasingly globalized. These terms are often used interchangeably although they are not synonymous. Internationalization is related with increasing geographical expansion of economic activities over a national country's border (Dicken, 2003, or, according to Hill, 2009). internationalization occurs as firms extend products and services into foreign markets, accordingly it is relatively easy to measure internationalization via the proportion of international sales (exportimport) to total sales Globalizations is more advanced and complex form of internationalization, emerging as the norm in a growing range of economic activities Dicken (2003) and is the process by which businesses 
create value by leveraging their resources and capabilities across borders, and includes the coordination of cross-border manufacturing and marketing strategies (Hill, 2009).

\section{Impact of exporting on economic development}

Accelerating changes of the global business environment evoke the need for an updated understanding of the possible benefits of exporting and in a new way to evaluate its attitude towards long term perspective. The obvious and potential benefit of exporting for the state's economic growth and development requires exploitation of propelling challenges in the global arena. It is widely accepted that an increase in the export volumes has a positive impact both on the development of separate regions, states as well as individual subjects of the economy (Rakauskiene, 2006). Regions and states, which are tied together by globalization, experience faster economic growth than the ones that integrate into the world economy at a slower pace.

Empirical researches (Sena, 2004; Kearney, 2004; Beck, 2006) reveal the impact of speedier globalization processes for the state's involvement into political, technological, cultural integration processes. Exports have become a major source of national income for many small, open economies and a source of growth and survival for many small and medium-sized and large enterprises, especially in Europe. World trade recorded its largest ever annual increase in 2010 as merchandise exports increased 14.5 per cent, buoyed by a 3.6 per cent recovery in global output as measured by gross domestic product (GDP) (World trade report, 2011).

As it could be seen from the Table 2, world GDP at market exchange rates increased by $3.6 \%$ in 2010 , one year after an unprecedented contraction of $2.4 \%$ that accompanied the financial crisis in 2009 , while world trade increase achieved 13.5 percent in 2010.

Table 1. GDP and merchandise trade by region, 2007-2010 (Annual \% change)

\begin{tabular}{|c|c|c|c|c|c|c|c|c|c|}
\hline & \multicolumn{3}{|c|}{ GDF } & \multicolumn{3}{|c|}{ Export:s } & \multicolumn{3}{|c|}{ Import:s } \\
\hline & 2000 & 20019 & 20100 & 2000 & 20019 & 2010 & 2000 & 2009 & 2010 \\
\hline World & 1.4 & -2.4 & 3.6 & 2.2 & -12.0 & 14.5 & 2.2 & -12.8 & 135 \\
\hline North America & 0.1 & -2.8 & 30 & 2.1 & -14.8 & 15.0 & -2.4 & -16.7 & 15.7 \\
\hline United States & 0.0 & -2.6 & 2.8 & 5.8 & -14.0 & 15.4 & -3.7 & -16.4 & 14.8 \\
\hline South and Central America a & a 5.1 & -0.2 & 5.8 & 0.8 & -7.9 & 6.2 & 132 & -16.3 & 22.7 \\
\hline Europe & 0.5 & -4.0 & 1.9 & 0.2 & -14.1 & 10.8 & -0.6 & -14.2 & 9.4 \\
\hline European Union [27] & 0.5 & -4.2 & 1.8 & 0.0 & -14.5 & 11.4 & -0.9 & -14.2 & 9.2 \\
\hline \multicolumn{10}{|l|}{ Commonwealth of } \\
\hline Independent Sitates [CIS] & 5.5 & -7.1 & 4.3 & 2.0 & -5.2 & 10.1 & 16.4 & -25.6 & 20.6 \\
\hline Africa & 4.8 & 2.1 & 4.7 & 1.2 & -4.2 & 6.5 & 14.6 & -5.0 & 7.0 \\
\hline Middle East & 53 & 0.8 & $3 s$ & 35 & -4.3 & 9.5 & 14.2 & -7.8 & 7.5 \\
\hline Asia & 2.8 & -0.2 & 63 & 5.5 & -11.2 & 23.1 & 4.7 & -7.5 & 17.6 \\
\hline Ehina & 9.6 & 9.1 & 10.3 & 8.5 & -10.5 & 28.4 & $3 s$ & 29 & 22.1 \\
\hline Jap:an & -1.2 & -63 & 39 & 2.2 & -24.8 & 27.5 & -1.0 & -12.2 & 10.0 \\
\hline India & 6.4 & 5.7 & 9.7 & 14.4 & -6.8 & 19.9 & 17.3 & -1.0 & 11.2 \\
\hline \multicolumn{10}{|l|}{ Newly industrialized } \\
\hline economies [4] b & 1.9 & -0.8 & 7.7 & 4.9 & -5.7 & 21.3 & 35 & -11.4 & 180 \\
\hline Memo: Developed economies & $=5.2$ & -3.7 & 2.6 & 0.8 & -15.1 & 12.9 & -1.2 & -14.4 & 10.7 \\
\hline Memo: Deueloping and Cis & 5.7 & 2.1 & 7.0 & 4.2 & -7.8 & 16.7 & 8.5 & -10.2 & 17.9 \\
\hline
\end{tabular}

a Includes the Caribbean.

b Hong Kong, China; Republic of Korea; Singapore and Chinese Taipei.

Source: World trade 2010, prospects for 2011

Therefore, the international trade can be seen as a crucial factor for success in development - without an increase in international exchanges, there can be no development.

Regarded as priority export orientation of a national economy is expected to ensure its sustainable and dynamic progress, economic and financial security and, in the end, growth of common wealth. Expansion of regional trade relations becomes intermediate necessary step striving to participate in the global trade and 
allows for business subjects to acquire necessary experience to successfully compete in the global markets (World trade report, 2011).

Considering the importance of exports for economic development, the question of the day is how states, regions and their economy subjects should improve export performance in the markets radically changed by globalization? Concept of export-led growth (growth though exports), especially stresses significance of exports for economic growth, accumulation of foreign exchange reserves, the necessity to create production facilities to serve export markets resulting in increased employment levels, to attract foreign private investment and technology to build new export industries with improves productivity and, ultimately - enhance prosperity, also to create export promotion and development strategies and export promotion institutional structure (Czinkota, 1994; Jatuliaviciene, Kucinskiene, 2005; Todaro, Smith, 2006).

The global market offers opportunities for exporting small to medium-sized enterprises products and services. Because there is no single globally accepted definition of SMEs, definitions of SMEs are various in different countries depending of the number of employees, kind of the economic activity and the amount of sales (Small and medium-sized enterprises: 2010). The European Union has adopted a new standardized definition of SMEs concerning the definition of micro, small and medium-sized enterprises with updated financial thresholds that entered into force for EU members on January 1, 2005. (Commission recommendation, 2003). This definition is to be used for all cases where eligibility is to be assessed and programms are to be targeted.

The export potential of small and medium-sized firms has been a growing subject of interest. Why should today's export promotion strategies focus on SMEs, rather than on large enterprises? Small and medium enterprises (SMEs) occupy unique position in most of the countries and are found in a wide array of business activities. SME does also play a central role in the European economy. In 2010 Europe's 23 million SMEs, accounted for two thirds of jobs in the private sector and $59 \%$ of total value added in the non-financial business economy as of 2010 around $80 \%$ of new jobs over the past five years have been created by SMEs (Small Business, Big World, 2010).

However, European SME's are ill equipped to capitalize on exporting opportunities. A considerable number of European SMEs are engaged in international activities yet only a small percentage is involved in internationalization beyond the Internal Market. The two most common modes of internationalization are exports and imports: $25 \%$ of SMEs within the EU 27 export, of which about $50 \%$ also go beyond the Internal Market (13\%); $29 \%$ of SMEs within the EU 27 import, again $50 \%$ import from countries outside the Internal Market (14\%). (Internationalization of European SME's, 2010). Europe needs to boost their internationalization process and provide the necessary support to SMEs when going international (Small Business, Big World, 2010).

\section{The concept of export promotion and export development}

Another important aspect in the research of exporting expansion is export promotion. Export promotion has become a popular policy for promoting economic development growth in state and local economies since the 1930's. Realignments on both macro and micro levels are occurring on a daily basis, making past orientations obsolete and compelling companies to seek new business beyond national borders. Exports and export promotion activity that have received interest only recently due to the balance of trade deficit, unemployment and domestic growth slowdown, are becoming important components of the state economic development program (Todaro, Smith, 2006). The promotion of export activities through government and other public or private sector institutions has received wide attention from both policy makers and academic researchers. This interest reflects, on the one hand, recognition of the potential usefulness of export promotion for businesses and, on the other hand, that the well-performed export promotion activities have a major impact on trading businesses competencies abroad and thus bring in the economic well-being of a country.

Governments consider exports as engine of growth and worldwide provide assistance applied to improve their enterprises performance by providing the knowledge and competence applied to export market develo- 
pment (Gencturk, Kotabe, 2001). As the states enter into more and more into international exchanges, new export promotion mechanisms evolve in the global trading system striving do not protect local industry but forcing it to compete internationally.

The broadest definition, presented by Czinkota, Ronkainen, Moeffett (2005) defines export promotion as the government attempts to stimulate exports by giving incentives to exporting firms. Incentive programs are designed to attract more firms into exporting by offering help in product and market identification and development, pre-shipment and post-shipment, financing, trading, payment guarantee schemes, trade fairs, trade visits, foreign representation, etc. (Export promotion. Business dictionary). Assistance for exporters may take many forms. Some of export promotion activities are new and not explored; others are widely used and confirmed empirically. The most interesting among them deal with exporting not as an end in it but as a part of a package of trade development initiatives.

The understanding that export expansion is needed to achieve further growth and development induced the governments of various countries to create export promotion policies, export strategies, establish export promotion institutions and create programms for export promotion. Successful export growth relies not only on governmental institutions activities but also on private sector institutions initiatives and activities. The who and where gives the assistance for exporters, and the form of assistance varies among the countries according to the country's history, political and economic circumstances, economic and social structure. This occurs because there is not uniform agreement on the nature or extent of involvement by private and public sector in export promotion.

Governments were responding to greater liberalization of foreign trade regulations and increased competition from abroad. Export promotion strategy is an important component of country's economic growth and development and is related with possibilities to increase exports. In a study about export performance of firms in Chile, Alvarez (2004) has shown that permanent and successful exporters have used public export promotion programms more intensively than less successful exporters. The further discussion of both such traditional and innovative approaches in export promotion or export development should shed more light into the matter.

Differences between two concepts export promotion and export development strategy evidence in their orientation. Export promotion activities are to encourage increased sales of products that are currently available for export. All promotional efforts are based on existing production and aim at increasing the value of foreign sales by a given target.

Today's export promotion strategies must reflect the changing nature of the international trade environment. As a reaction to the challenges of the contemporary globalization processes, many scientists, such as Hibbert (1998), Czinkota (2002), Evans (1997) distinguished new and innovative approach to export promotion that is export development conception which emphasizes the importance of non-traditional export development. This type of development would include creation of new exportable products and/or penetration into the new, previously inapproachable, markets as well as development and diversification of non-traditional export areas thus creating more dynamic and competitive business environment. Representatives of this concept argue that for the research and implementation of export development methods and means there is a need to identify opportunities, which not only allow sustaining traditional markets or entering the new ones, but also provide help while creating competitive advantages in the enterprise, product sector and state levels.

The export development approach clearly requires more effort, resources, and persistence than the simple traditional export promotion approach (Hibbert, 1998). Both strategies, export development and export promotion, have their own rationale and are related to different problems and consequences for a country.

States are not always capable of fully implementing export development due to specific restrictions that exist internally. Management of successful export development processes is a complex task, as it requires a lot of efforts, resources and persistence in comparison with traditional export promotion methods. The challenges in the management of export development in the context of global area create new requirements for the states, their national institutions and economy subjects. They are challenged to adopt new strategic export development decisions that would encourage focus on the creation and acceptance of new skills. Such inno- 
vations would allow overstep the boundaries of traditional business and enable the acquisition of competitive advantage in the global area product markets.

\section{Lithuanian export development subjects interests' diagnostics}

Lithuania, as a small country, with small domestic market, historically has had little choice but to implement export led-growth. Foreign trade now plays a significant role in determining the overall growth rate of the Lithuanian economy. Export of goods and services is regarded in Lithuania as one of the most important priorities of national economy development. Lithuania has a very open market and carries out most of its foreign trade with the EU. The trade to GDP ratio reached 126.7 percent in 2008-2010 (Country profile: Lithuania)

In 2010 Lithuanian merchandise exports reached 20.8 billion US\$ and commercial services exports 4,07 billion respectively (Country profile: Lithuania). Lithuanian foreign trade shows a deficit insofar as the value of imports is greater than that of exports. This can largely be explained by the fact that the country imports a large quantity of gas from Russia, whose prices were raised in recent years.

The export performance of SMEs is of great significance to Lithuania, given the contribution of small and medium-sized business to economic growth and job creation. The Lithuanian export promotion system is in accordance with relevant international rules (WTO and EU rules and regulations) and enables Lithuanian exporters to participate under fair competitive conditions in international markets. Overall, Lithuania has reshaped incentives provided to exporters, eliminated subsidies in order to harmonize foreign trade policies and increased transparency of export subsidy programs. Due to WTO regulations and EU Customs Union, Lithuania now applies measures indirectly assist exporters such as: export finance and insurance as well as marketing assistance. However, large scale export promotion programms are difficult to implement under the budget constraints. Active debate about export promotion system reform concerns questions of an export promotion support access evaluation.

The aim of the research. To reveal Lithuania's SMEs export development possibilities improvement during the process of internationalization in the context of current state of globalization.

In order to achieve the aim of the research detailed objectives are formulated:

1. To reveal obstacles that are suppressing Lithuanian SME's export development and to evaluate motivation for Lithuanian export promotion activity transformation through the use of empirical research.

2. Through the use of the results from the empirical research, to foresee areas and means for the improvement of Lithuanian SMEs exporting.

The following criteria for the achievement of empirical research aims were distinguished:

1. By type of impact (influence on export growth).

2. By impact object (SME's in manufacturing industry and services (wholesale and retail trade and construction) industries.

3. By utility of impact according to internationalization stages.

Survey data has been used to test statistical hypotheses:

H.1. Evaluation of export promotion encouragement depends on the type of firm's activity area;

H.2. With the growing export experience, the application of export promotion is evaluated more favorably.

The survey questionnaires were based on theoretical considerations. Based on the parameters of this material sampling, adaptation to empirical research, has been identified, and questions had been formulated. Questionnaire consists of open and closed questions which are divided into two parts. First part of the questionnaire analyzes current situation of respondents' enterprises exporting situation whilst defining their current internationalization stage. In the second part, testing of raised hypotheses is conducted and respondent attitude to export promotion state is identified. 
During research 380 Lithuanian enterprises were questioned. Survey data were processed and analyzed by using statistical data analysis methods such as statistical data analysis packet SPSS 13.0, Mann-Whitney and Kruskal-Wallis test criteria as well as Spearman correlation ratio.

The results of the research

Striving for long term economic growth under conditions of current globalization, at first it is needed to evaluate current economy's exporting position and potential

As the respondents named the types of economic activities they are in, while answering questions based on the nominal scale, their answers showed that more than half of the enterprises operated within the manufacturing sector -52.6 percent while less than half of them operated within trade and construction sectors47.4 percent. Through the use of the interval scale, responses regarding length of companies' activities were gathered. The results showed that there were 21.1 percent of companies that had the operational history of up to 5 years, 40 percent five to nine years, 30.3 percent ten to fifteen years and 8.7 percent operated longer than 20 years. According to the size of the companies by the number of people employed, there were 23.2 percent of up to 9 employees, 55.8 percent of 10 employees and 21 percent of the companies had 50 to 249 employees.

The experience in the export activities was measured, and the results revealed (see $x$ table) that 13.4 percent of the companies have never exported and show no intention to do so. 7.9 percent of the companies with no exporting experience wanted to start internalization process.

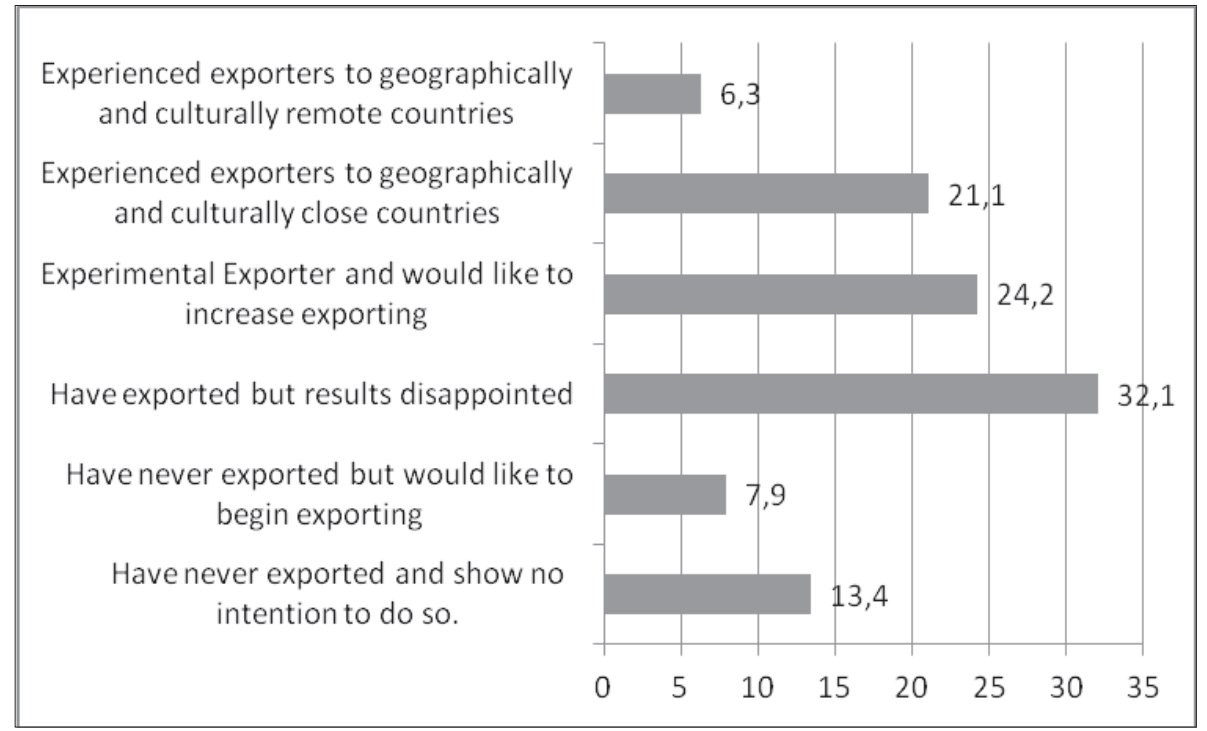

Figure 1. The experience in export activities

There were not many companies that would consider themselves as experienced exporters to geographically and culturally remote countries -6.3 percent. The majority of the researched companies failed upon their first exporting experiences -32.1 percent. There were 24.3 percent of the companies that successfully exported and wanted to expand their export further and 21.1 percent of the companies were experienced exporters selling to geographically and culturally proximate countries.

Evaluating export involvement, enterprises that only fulfill occasional export orders, make up for just over one fifth of the responders -21.3 percent. Companies that fulfill regular export orders, but do not intend to research active export possibilities are dominating the research -35.8 percent. Only 18.4 percent of respondents are actively researching the possibilities to export. Furthermore, only 6.3 percent of the companies had prepared an export marketing plan. Similarly, only 6.1 percent of the companies have prepared their long-term export strategy. 


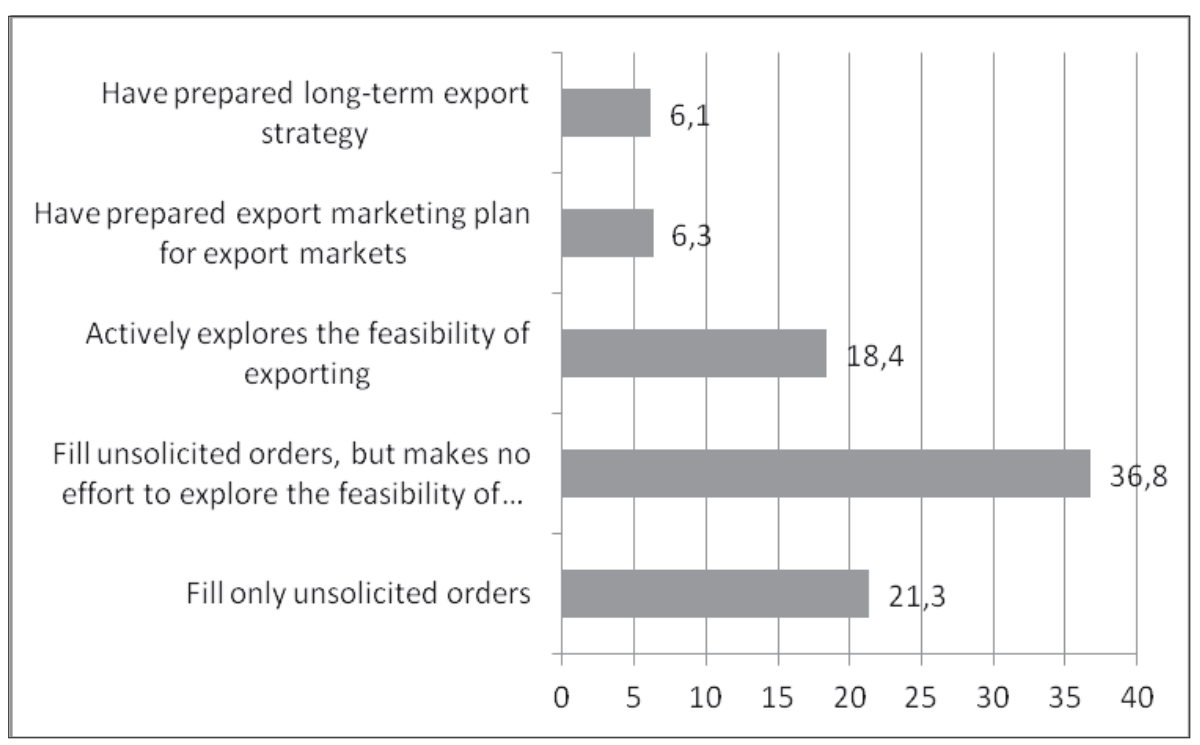

Figure 2. Export involvement evaluation

The majority of the respondents (61.8 percent) were companies whose export part of sales was 10 to 49 percent, 26.2 percent of the companies had 10-19 percent export part of sales, 35.6 percent had 20 to 49 percent and 16.1 percent had more than 50 percent of export as part of their sales. Equally, 11.4 percent and 10.7 percent of the companies had accordingly up to 5 percent or 5 to 9 percent as their export part from the sales.

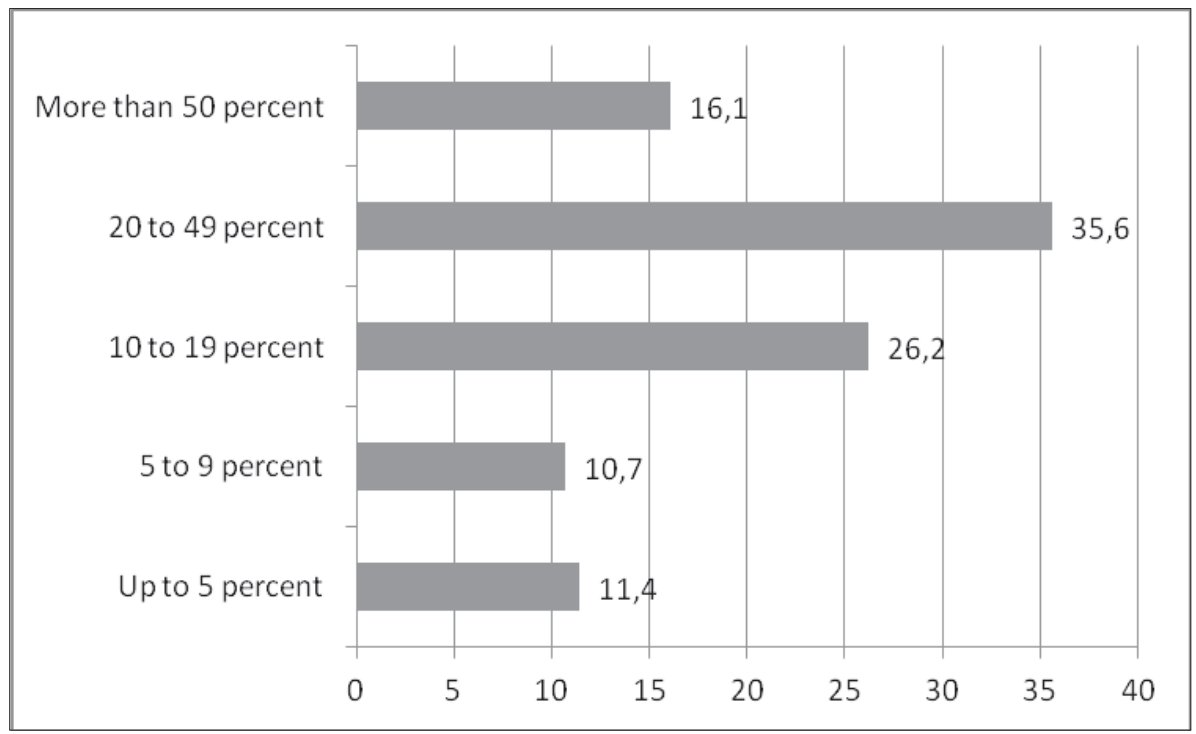

Figure 3. Export part of sales

In regards to the levels of goods and services adaptation and standardization levels, almost half of the exported products are the same as the products being sold internally -44.6 percent. Products, which have been minimally adapted, play quite a significant role reaching to 33.9 percent. However, only 19.6 percent of adapted and/or new products are exported to the foreign markets.

The export-led growth strategy is not an un-mixed blessing and its success is conditioned by the export of diversified capital intensive and value-added products 
While evaluating the help in promoting export, the majority of respondents thought it was average (44.1 percent), 31.4 percent believed it to be negative and only 24.6 percent evaluated the help positively.

During the analysis of respondent opinion on the export promotion evaluation, some of hypothesis were sought to confirm:

Hypothesis 1: Evaluation of export promotion encouragement depends on the type of company's activity area

From all of the respondents that negatively evaluated export promotion, 56.8 percent were manufacturing and 43.2 percent were services sector companies. Within the manufacturing companies, 33.7 percent evaluated the help negatively. In the services sector 28.7 percent evaluated the help negatively.

From all of the respondents that positively evaluated export promotion in Lithuania, manufacturers make up to 42.5 percent and service industries -57.5 percent. Within the manufacturing companies, 19.8 percent evaluated the help positively. Within the services industry, 29.9 percent evaluated the help positively. The help was valued as average by 55.8 percent of manufacturing companies and 44.2 percent service companies' respondents.

It can be thus confirmed that opinion on export development evaluation and the type of firm's activity area are not related, i.e. the differences of opinions are statistically unimportant since (Chi-Square) $p=0,085$, hypothesis is not confirmed.

Hypothesis 2: With the growing export experience, the application of export promotion is evaluated more favourably.

Among the companies that have never exported and are not intending to do so, 16.7 percent evaluated the export promotion encouragement negatively, which represented 7.2 percent of overall respondents. 18.8 percent evaluated help favorably, which represented 10.3 of overall respondents. 64.6 percent or 19.9 percent of overall respondents evaluated help as being average. Since $p=0.007$, there is a dependency and the numbers are statistically reliable.

Among the companies that have never exported but would like to start the export, the export promotion help was valued favorably by 21.5 percent of respondents, or 6.9 percent of overall respondents with 25.0 percent (or 6.3 percent overall) valuing it negatively and 53.6 percent (or 9.6 overall) valuing it as being average. Since $p=0.0556$, the valuation of export promotion and export experience are not interrelated, i.e. statistically insignificant.

Having compared the results for the statement "Started exporting but the results were disappointing" together with "How do you value export promotion help in Lithuania", 28.0 percent or 29.7 percent of overall respondents valued it negatively and 40.7 percent or 30.8 percent of overall respondent valued the help as being average. 31.4 percent or 42.5 percent of overall respondents valued help positively. Since $p=0.110$ the differences are statistically insignificant. It is confirmed then, that respondents that experienced export downfalls, also value export promotion help in Lithuania negatively.

Among the experimental companies that have successfully exported and wanted to carry on, export promotion help was valued unfavorably by 51.7 percent of respondents, or 41.4 percent of overall respondents, with 28.1 percent (or 16.0 percent overall) valuing it as being average and 20.2 percent (or 20.7 overall) valuing it favorably. Since $\mathrm{p}=0.000$, values are statistically reliable.

Among the companies that are experienced exporters into geographically and culturally close markets, export promotion help was valued unfavorably by 20.0 percent of respondents, or 11.7 percent of overall respondents. 15.4 percent (or 11.5 percent of overall respondents) valued the help favorably. 64.6 percent (or 26.9 percent of overall respondents) did not have an opinion. Since $p=0,001$, values are statistically reliable.

Among the companies that are experienced exporters into geographically and culturally distant markets, export promotion help was valued favorably by 56.6 percent of respondents, or 14.9 percent of overall respondents. 21.7 percent (or 3.2 percent of overall respondents) did not have an opinion while 21.7 percent (or 4.5 percent of overall respondents) valued the help unfavorably. Since $p=0.001$, values are statistically reliable. 
It can be therefore summarized, that research results showed interdependence between company's internationalization level and its opinion toward the usefulness of export promotion, most favorably evaluated by the experienced exporters into geographically and culturally close markets. Hypothesis, that with the growing export experience, the application of export promotion is evaluated more favorably, was partially confirmed.

\section{Conclusions}

Current internationalization and globalization processes create new opportunities and challenges for international business development. Considering export benefit, every state is interested in active support as for its economy subjects export opportunities improving, as helping for current or potential exporters to widen or strengthen their activities in the international markets. Regarded as priority export orientation of the national economy is expected to ensure its sustainable and dynamic progress, economic and financial security and, in the end, growth of common wealth

Support for SME's and their goods and services becomes prerogative, therefore export promotion means should be more oriented to SME's enterprises

Export promotion means should provide better accesses to the recent foreign markets and more knowledge about them. Export development aims at producing new export products and/or penetrating new markets that were not accessible before. Strategic implications should be specific programs to address the constraints for exporters in different internationalization stages.

Lithuania depends heavily on trade in general. The majority of the country's exports come to European Union member countries. Empirical research on Lithuanian SME's revealed a rather pessimistic evaluation of current export development condition and disadvantages of Lithuania SMEs export supply, as well as lack of knowledge on export promoting institution help.

Research also revealed the need for more value added exports, more adapted or new products and enlarging the involvement base of Lithuanian SME's companies in exporting. Export promotion and development support should be oriented to providing better access to the foreign markets and more knowledge about them providing specific programs to address the constrains.

Export encouragement, the choice of priority subjects, identification of the most perspective export development markets for SMEs, depending on the stage of internationalization as well as concentrated export support towards those SMEs, in authors' opinion, would allow seeking for directed export development in the context of globalization conditioned integration processes.

Improving export promotion and development activities in Lithuania would strengthen its export capability, enhance its competitiveness and boost demand for products, thereby stimulating economic growth and development in the global market.

\section{References}

Albaum, G., Duerr, E., Strandskov, J. (2005). International Marketing and Export Management. 5th ed. Pearson Education.

Alvarez, R. (2004). Sources of export success in small and medium-sized enterprises: the impact of public programs. International Business Review, No. 13, p. 383-400.

Bilkey, W. J., Tesar, G. (1977). The Export Behaviour of Smaller-sized Wiskonsin manufacturing Firm. Journal International Business Studies, No. 9 (Spring/Summer), p. 93-98.

Beck, U. (2006). Cosmopolitan vision. Cambridge, UK: Polity Press.

Cavusgil, S. T. (1980). On the internationalization of firms'. European Research, Vol. 8, November, p. $273-81$.

Commission Recommendation 2003/361/EC of 6 May 2003 concerning the definition of micro, small and mediumsized enterprises [Official Journal L 124 of 20.05.2003].

Country profile: Lithuania. Website: http://stat.wto.org/CountryProfile/WSDBCountryPFView. aspx? Language $=\mathrm{E} \&$ Country $=\mathrm{LT}$ 
Czinkota, M. R. (2002). Export promotion: a framework for finding opportunity in change. Thunderbird International Business Review, Vol. 44 (3), p. 315-324.

Czinkota, M. R., Ronkainen, A., Moeffett, M. H. (2005). International business. 7th ed. Thomson.

Daniels, J. D., Radebaugh, L. H., Sullivan, D. P. (2007). International Business. Environments and Operations. $11^{\text {th }}$ ed. Upper Saddle River/NJ. Prentice Hall.

Dicken, P. (2003). Global Shift. Reshaping the Global Economic Map in the 21st Century. $4^{\text {th }}$ edition. The Guilford Press.

Export promotion. Business dictionary. Website: http:/www.businessdictionary.com/definition/export-promotion.html

Evans, P. (1997). The Eclipse of the state. World Politics, No. 50, p. 62-87.

Jatuliavičienè, G., Kučinskienè, M. (2006). Impact of globalization processes on Lithuanian industry development perspectives. Proceedings of the 16th International Scientific Conference Modern Approaches to Corporate Management. Slovak Republic: Slovak University of Technology in Bratislava.

Gencturk, E. F., Kotabe, M. (2001). The effect of export assistance program usage on export performance: a contingency explanation. Journal of International Marketing, Vol. 9, No. 2, p. 51-72.

Hill, J. S. (2009). International business: Managing Globalization. SAGE publications.

Internationalisation of European SMEs. Final Report. (2010). Website: http://ec.europa.eu/enterprise/policies/sme/ market-access/files/internationalisation_of_european_smes_final_en.pdf

Johanson, J., Wiedersheim, P. F. (1975). The internationalization of the firm - Four Swedish cases'. The Journal of management studies, No. 12, p. 305-322.

Johanson, J., Vahlne, J. E. (1977). The Internationalization Process of Firm - A Model of Knowledge Development and Increasing Foreign Market Commitments. Journal of International Business Studies, Vol. 8, No. 1, p. $23-32$.

Johanson, J., Vahlne, J. E. (1990). The Mechanism of Internationalization. International Marketing Review, Vol. 7 , No. 4, p. 11-24.

Hibbert, E. P. (1987). The Principles and Practice of Export Marketing. Heineman: London.

Kearney, A. T. (2004). Measuring globalization. Foreign Policy Magazine, No. 3-4, p. 54-69.

Kotabe, M., Czinkota, M. R. (1992). State government promotion of manufacturing exports: a gap analysis. Journal of International Business Studies, Vol. 23, No. 4, p. 637-658.

Kučinskienė, M., Jatuliavičienė, G. (2002). Globali ekonomika ir antreprenerystè. Ekonomika: mokslo darbai, Lietuvos ekonomika ir globalizacija, Nr. 60(2), p. 69-78.

Kučinskienė, M., Jatuliavičienè, G. (2005). Globalization challenges and environment dynamics. Business development possibilities in the new European area. Scientific proceedings. Part 1. Vilnius. Lithuania. 23-24 September. Vilnius University, Faculty of Economics, p. 143-147.

Kotabe, M., Czinkota, M. (1992). State Government Promotion of Manufacturing Exports: A Gap Analysis. Journal of International Business Studies, No. 23, p. 637-658.

Rakauskienė, O. G. (2006). Valstybès ekonomine politika. Vilnius: Mykolo Riomerio Universiteto leidybos centras.

Sena, V. (2004). The return of the prince of Denmark: a survey of recent developments in the economics of innovation. Economic Journal, No. 114 (496), p. 312-332.

Small and Medium-Sized Enterprises: U.S. and EU Export Activities, and Barriers and Opportunities Experienced by U.S. Firms. (2010). U.S. International Trade Commission Investigation, No. 332-509 Publication 4169 July 2010. Website: http://www.usitc.gov/publications/332/pub4169.pdf

Small Business, Big World - a new partners hip to help SMEs seize global opportunities. (2011). Communication from the Commission to the European parliament, the council, the European economic and social committee and the committee of the regions. European commission. Website: http:/ec.europa.eu/enterprise/policies/sme/market-access/ files/communication_sme_internationalisation_draft_en.pdf

Todaro, M. P., Smith, S. C. (2006). Economic Development. 9th edition. Addison-Wesley, Boston et al.

Welch, L. S., Luostarinen, R. K. (1988). Internationalization: Evolution of a Concept. Journal of General Management, Vol. 14, No. 2, p. 36-64.

World trade 2010, prospects for 2011. Website: http://www.wto.org/english/news_e/pres11_e/pr628_e.htm World trade report 2011. Website: http://www.wto.org/english/res_e/booksp_e/anrep_e/world_trade_report11_e.pdf 


\section{SMULKAUS IR VIDUTINIO VERSLO İMONIŲ EKSPORTO SKATINIMO POKYČIAI LIETUVOJE, EKSPORTO PLËTROS KRYPTYS}

GražIna JatuliaviČIENĖ, MariJa KuČInSKIENĖ

Vilniaus universitetas (Lietuva)

Santrauka

Šiuolaikinès integracijos tendencijos, nulemtos globalizacijos procesų, skatina kurti naujus eksporto plètros kryptis ir plètros metodus. Jų ivertinimas ir igyvendinimas yra svarbi varomoji jèga ekonominiam augimui ir darniam regionų vystymuisi. Straipsnyje siekiama atskleisti, kad dabartinė Lietuvos valstybès pozicija, issitraukiant ị tarptautinius mainus dinamiškoje globalioje aplinkoje, eksporto skatinimo požiūriu turi būti konceptualiai pagrista, leidžiant lygiaverčiai dalyvauti tarptautinėje prekyboje ir tinkamai reaguoti i globalizacijos iššūkius. Svarbiausia, kad eksporto skatinimo ir eksporto plètros mechanizmai bei instrumentai leistų laiku reaguoti į vis spartẻjantį ekonominių santykių liberalizavimą ir skatintų ekonominị augimą, atsižvelgiant į eksporto plètrą.

PAGRINDINIAI ŽODŽIAI: internacionalizacija, globalizacija, smulkus ir vidutinis verslas, eksporto skatinimas, eksporto pletra.

JEL KODAI: F130; F140; F150; O110; R110. 